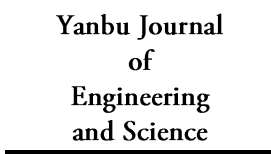

ISSN: 1658-5321
Vol. 3, October $2011(1432 \mathrm{H})$

www.yjes.org.sa

\title{
A NOVEL VARIABLE HYSTERESIS BAND CURRENT CONTROLLED VSI FED INDUCTION MOTOR DRIVES
}

\author{
E. E. El-kholy' ${ }^{1}$, Ahmed E.kalas², and M. El-Shahat Dessouki ${ }^{1}$ \\ 1 Electrical Engineering Department, Faculty of Engineering, Rabigh, King Abdulaziz University, Saudi Arabia \\ e_mail: eelkholy@yahoo.com \\ 2 Electrical Engineering Department, Faculty of Engineering, Port Said University, Egypt
}

\begin{abstract}
The most problem associated with the conventional two-level three phase hysteresis controller is variation of switching frequency over the entire operating speed range of an induction motor (IM) drive. This paper presents a new variable band hysteresis current controller (NVB-HCC) for controlling the switching frequency variation in the two-level PWM inverter fed IM drives for various operating speeds. A novel concept of online variation of the band based on both the instantaneous load current and current change for each sampling period is presented to determine the hysteresis band. To verify the feasibility of the proposed scheme, computer Simulations and experiment results are provided. These results demonstrate that the proposed method can obtain constant switching frequency and improve the performance of the IM drive system.
\end{abstract}

Keywords: Induction motor control, Voltage source inverter

\section{INTRODUCTION}

Current controlled PWM (CC-PWM) voltage source inverters (VSIs) are extensively employed in High Performance Drives (HPD) because of the considerable advantages offered by them as compared to the voltage controlled PWM (VC-PWM) VSIs [1]-[3]. Various techniques for current controller have been proposed, amongst which the hysteresis controllers are widely used because of their inherent simplicity, easy implementation, insensitivity to load parameters variation and fast dynamic response [3-6]. However, the conventional type of hysteresis controllers suffers from drawbacks, e.g. limit cycle oscillations, overshoot in current error, generation of sub-harmonic components in the current and random (non-optimum) switching [4-5,7-8]. To eliminate these basic drawbacks, different types of fixed tolerance bands (hexagonal, circular, rectangular, etc., [7]) of current error space phasor based hysteresis controllers are reported in the literature [3], [5]-[7], [9]-[14]. However, the common problems associated with the conventional fixed band hysteresis controllers are the variation of switching frequency in the fundamental output cycle and variation of switching frequency with the variation in the speed of the load motor [14]-[16].

Variable switching frequency causes three main problems: High total harmonic distortion (THD) in the load current and this causes overheated machines and hamper the design of low order harmonic filters; increases the interference between phases (in three phase systems) in case of isolated neutral or delta connected systems as a result the current error increases and can reach twice the hysteresis band; and irregularity of 
modulation pulses which causes a torque ripple that result in speed oscillation and mechanical vibration. These problems reduce the drive performances. To overcome these problems, many authors have been interested to develop some algorithms to improve the characteristics of the hysteresis control technique. An adaptive hysteresis band current control technique presented in [15] programmes the hysteresis band (individual band for each phase of machine) as a function of load and supply parameters to optimize the PWM performance. A sinusoidal band hysteresis current controller, proposed in [16], leads to the higher average switching frequency compared to the corresponding fixed band hysteresis controller and hence demands for proper lockout of the switching frequency, which may cause current distortion. A combination of mixed-band (sinusoidal band added to a fixed band) and equidistantband hysteresis current controllers is emphasized in [17], which eliminates the additional lockout circuits. Another alternative for the variable band hysteresis controller suggested in [18] uses complex feedback and feed forward control blocks. In an adaptive hysteresis band current control strategy proposed in [19], the hysteresis band equation is derived as a function of q-axis reference current (variations of load), speed and neutral voltage of the motor (PMS M) in order to hold the switching frequency constant.

An improved constant-frequency hysteresis controller [20] uses analog feed forward for prediction of the band in addition to the phase-locked-loop control. However, the band control schemes presented in [15]-[20] are either complex to implement, requires extensive knowledge of the system parameters, suffer from the stability problems, or have limitations in transient performance. Also, more importantly, though in [15]-[20] the efforts are made to control the switching frequency in a fundamental cycle, however, the variation of switching frequency over various operating speed ranges of the machine is not examined. This paper describes a new simple variable band hysteresis current controller for controlling the switching frequency variation in the two-level PWM inverter fed IM drives. A novel concept of continuously varying the hysteresis band for the controller is suggested in order to insure a constant switching frequency. As a result, the current error, torque oscillation, and load current THD are decreased very effectively. To verify the feasibility of the proposed scheme, computer simulations and experiment results are presented.

\section{NEW VARIABLE BAND (NVB) HYSTERESIS CURRENT CONTROL SCHEME}

The predictive hysteresis-band current control scheme is suggested to achieve constant switching frequency and more precise current control with minimum harmonic distortion.

The design of this predictive hysteresis-band current controller depends on two main parameters one of them is the value of the instantaneous current at a certain time or a certain period (n, n-1) and the second is the value of the current change during this period [21]. Then, the algorithm uses the results of previous switching cycles to forward estimate the future load current. 


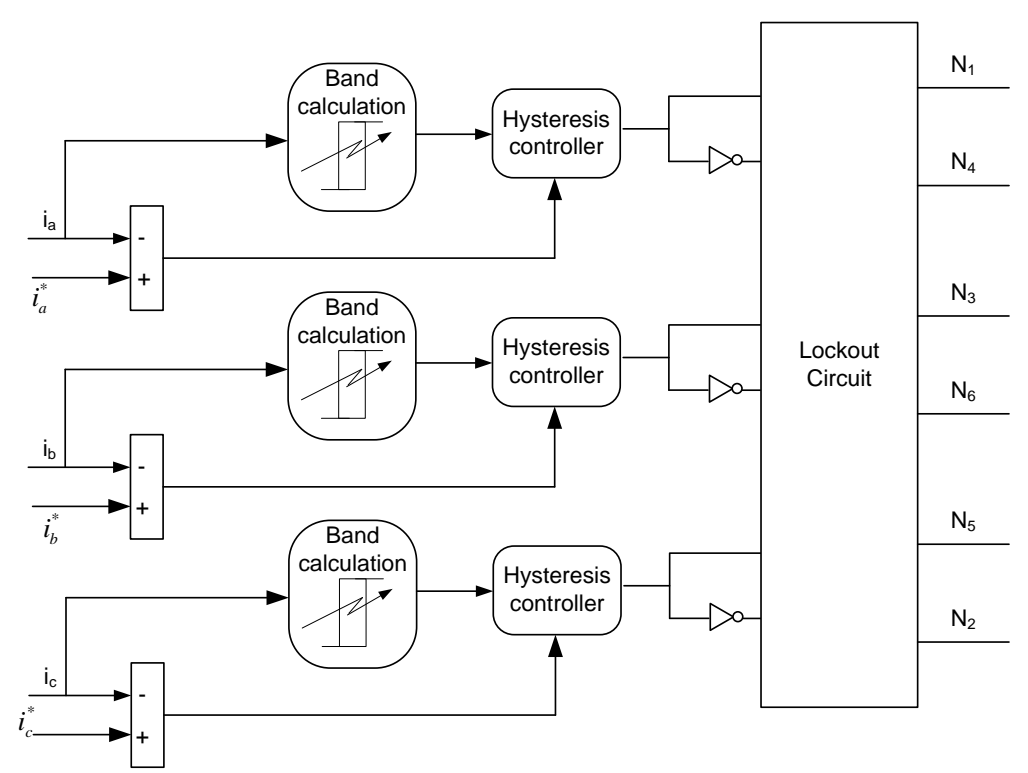

Fig.1. The proposed variable band HCC scheme

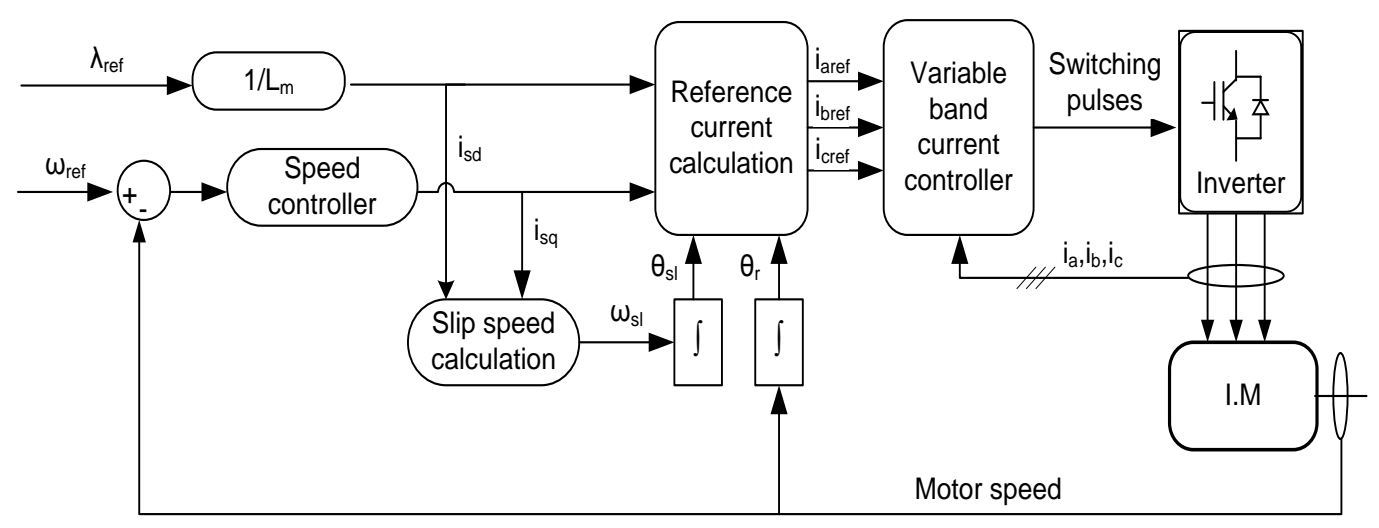

Fig.2. IFOC scheme under the proposed current controller for IM drive

The basic variable band current control scheme is shown in Fig. 1. In this scheme, the actual load currents are sampled and the corresponding current changes are calculated for each motor phase, for each sampling instant, and hence the band can be obtained as follow:

$$
\begin{aligned}
& \mathrm{H}_{\mathrm{a}}(\mathrm{n})=\mathrm{k}_{1} \mathrm{i}_{\mathrm{a}}(\mathrm{n})+\mathrm{k}_{2} \Delta \mathrm{i}_{\mathrm{a}}(\mathrm{n}) \\
& \Delta \mathrm{i}_{\mathrm{a}}(\mathrm{n})=\mathrm{i}_{\mathrm{a}}(\mathrm{n})-\mathrm{i}_{\mathrm{a}}(\mathrm{n}-1)
\end{aligned}
$$

Where $\mathrm{H}_{a}(\mathrm{n})$ is the phase "a" band at $\mathrm{n}$-th sampling instant, $i_{a}(n)$ is the phase "a" motor current at $\mathrm{n}$-th sampling instant, $\Delta \mathrm{i}_{\mathrm{a}}(\mathrm{n})$ phase "a" current change at $\mathrm{n}$-th sampling instant and $i_{a}(n-1)$ is phase "a" current at (n-1) th sampling instant, Where $K_{1}$ and $K_{2}$ are constants and these constants are calculated by trial and error methods in this paper.

We notice from "(1)," and "(2)," that at each sampling period the band is updated according to the value of the actual load current and the current change. Based on this new band, reference current and actual current the inverter switching action is generated and the actual load currents follow the reference ones. 
By developing this new online variable band, the inverter switching frequency is maintained constant as we will indicate in the experimental results.

\section{SIMULATION RESULTS}

This section presents the computer simulations for the proposed and conventional control schemes for induction motor drive fed with VSI based indirect field oriented control (IFOC) as shown in Fig.2 for different operating speeds.

To demonstrate the performance of the proposed scheme, some simulations from the proposed scheme are compared with those from the conventional control scheme using Simulink tools on Matlab platform. The parameters of the IM used are given in Appendix. For speed command of $1500 \mathrm{rpm}$ and rated load of $7.5 \mathrm{Nm}$ conditions, the steady state simulation waveforms of the phase current and its corresponding harmonic spectrum, torque and flux locus of the both the fixed band and the proposed (NVB) hysteresis current control schemes in one phase are contrasted in Figs 3 and 4 . Obviously the proposed control scheme gives smaller current ripple; current THD, torque and flux ripple than the fixed band HCC. These data are summarized in table 1.

Similar responses of the drive for both control schemes are shown in Figs. 5 and 6 respectively, at speed command of $200 \mathrm{rpm}$ and rated load. These data are summarized in table 2.
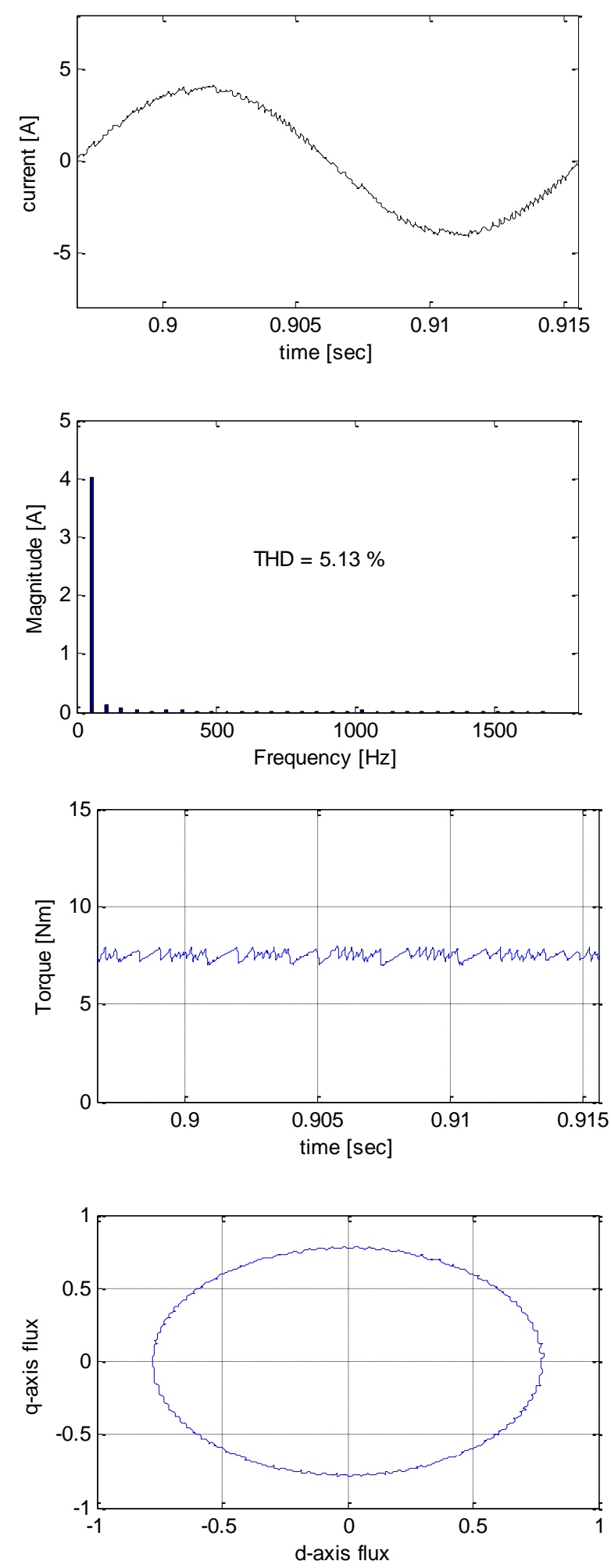

Fig. 3. Simulation waveforms of phase 'a' current and its THD, developed torque and flux locus in case of conventional fixed band hysteresis control method at speed command of $1500 \mathrm{rpm} \& 7.5 \mathrm{Nm}$ load torque 

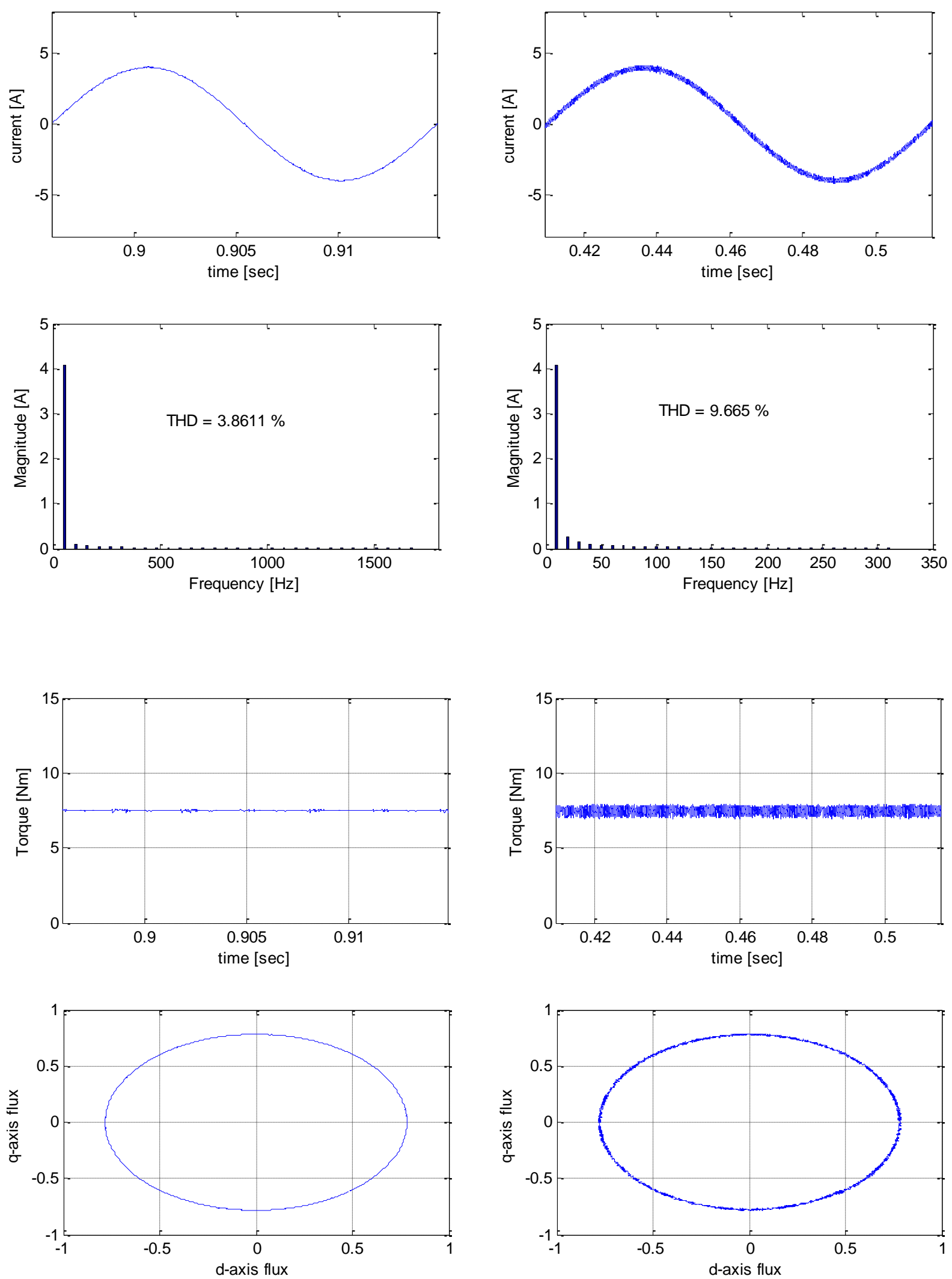

Fig. 4. Simulation waveforms of phase 'a' current and its THD, developed torque and flux locus in case of the proposed (NVB) control method at speed command of $1500 \mathrm{rpm} \& 7.5 \mathrm{Nm}$ load

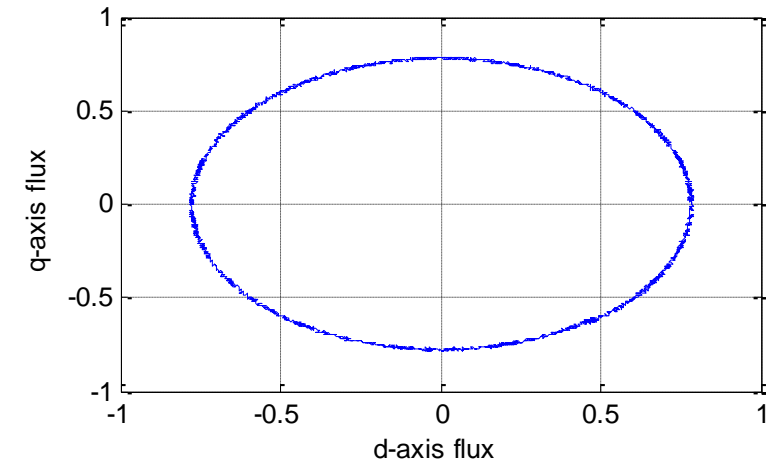

Fig. 5. Simulation waveforms of phase 'a' current and its THD, developed torque and flux locus in case of conventional fixed band hysteresis control method at speed command of $200 \mathrm{rpm} \& 7.5 \mathrm{Nm}$ load torque 

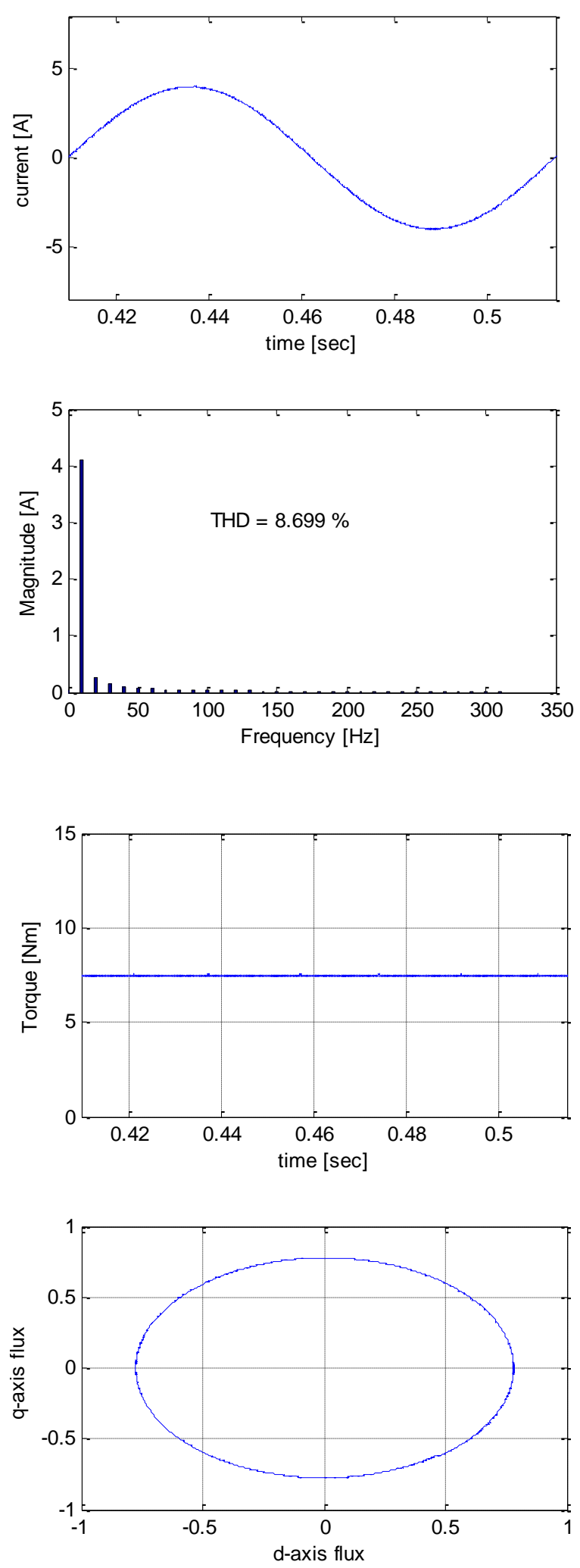

Fig. 6. Simulation waveforms of phase 'a' current and its THD, developed torque and flux locus in case of the proposed (NVB) control method at speed command of $200 \mathrm{rpm} \& 7.5 \mathrm{Nm}$ load torque
Also it is clear that, the proposed scheme gives better performance than the conventional fixed band control scheme.

\section{TABLE 1: DRIVE RESPONSE AT HIGH SPEED \& FULL LOAD CONDITION}

\begin{tabular}{|c|c|c|c|}
\hline Method & THD \% & $\mathrm{T}_{\text {osc }} \%$ & $\mathrm{~F}_{\mathrm{osc}} \%$ \\
\hline Fixed band & 5.13 & 14.88 & 2.63 \\
\hline Proposed & 3.861 & 3.3269 & 0.4772 \\
\hline
\end{tabular}

TABLE 2: DRIVE RESPONSE AT LOW SPEED \& FULL LOAD CONDITION

\begin{tabular}{|c|c|c|c|}
\hline Method & THD \% & $\mathrm{T}_{\mathrm{osc}} \%$ & $\mathrm{~F}_{\mathrm{osc}} \%$ \\
\hline Fixed band & 9.665 & 14.206 & 3.432 \\
\hline Proposed & 8.69 & 3.793 & 1.4119 \\
\hline
\end{tabular}

\section{EXPERIMENTAL RESULTS}

A complete CC-VSI fed IM drive based IFOC has been implemented as shown in Fig. 7 using DSP controller board DS1104 to verify the robustness of the proposed current control scheme. In the experiments, a threephase squirrel-cage IM is used, and the sampling time is set to $0.0001 \mathrm{~s}$. The parameters are the same as in the previous simulation test IM. The converter and PWM inverter have been implemented using a power diode and IGBT, respectively. Base drive and snubber circuits are also used here. Hall Effect closed loop transducers are used for sensing currents and voltages. A speed encoder supplying 2048 pulses/revolution is used for speed feedback.

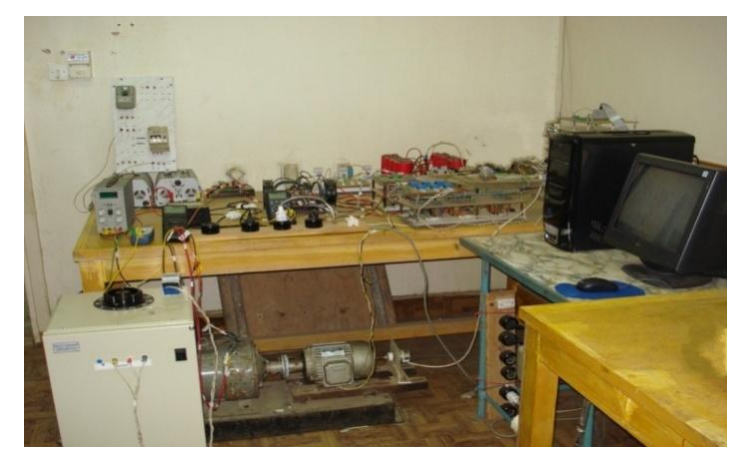

Fig. 7. Experimental setup of CC-VSI fed IM drive. 
For speed command of $120 \mathrm{rad} . / \mathrm{sec}$. and no load conditions, the speed response, stator currents, actual and reference current and switching frequency variation for both fixed band and the proposed (NVB) hysteresis current controllers are shown in Figs. 8 and 9, respectively. These figures reveal that the proposed control scheme has constant switching frequency; actual current tracking to the reference one with high accuracy and satisfactory speed response performance.
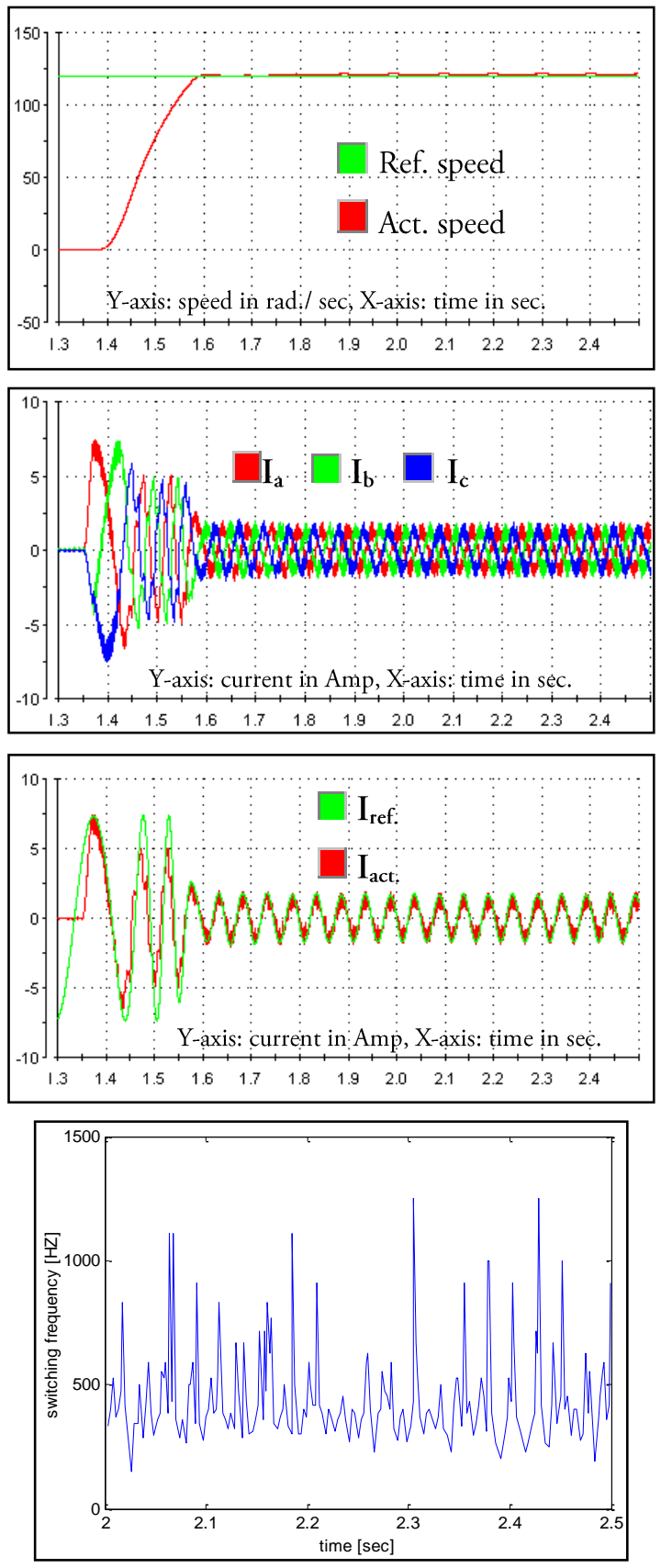

Fig. 8. Experimental results of Fixed band HCC
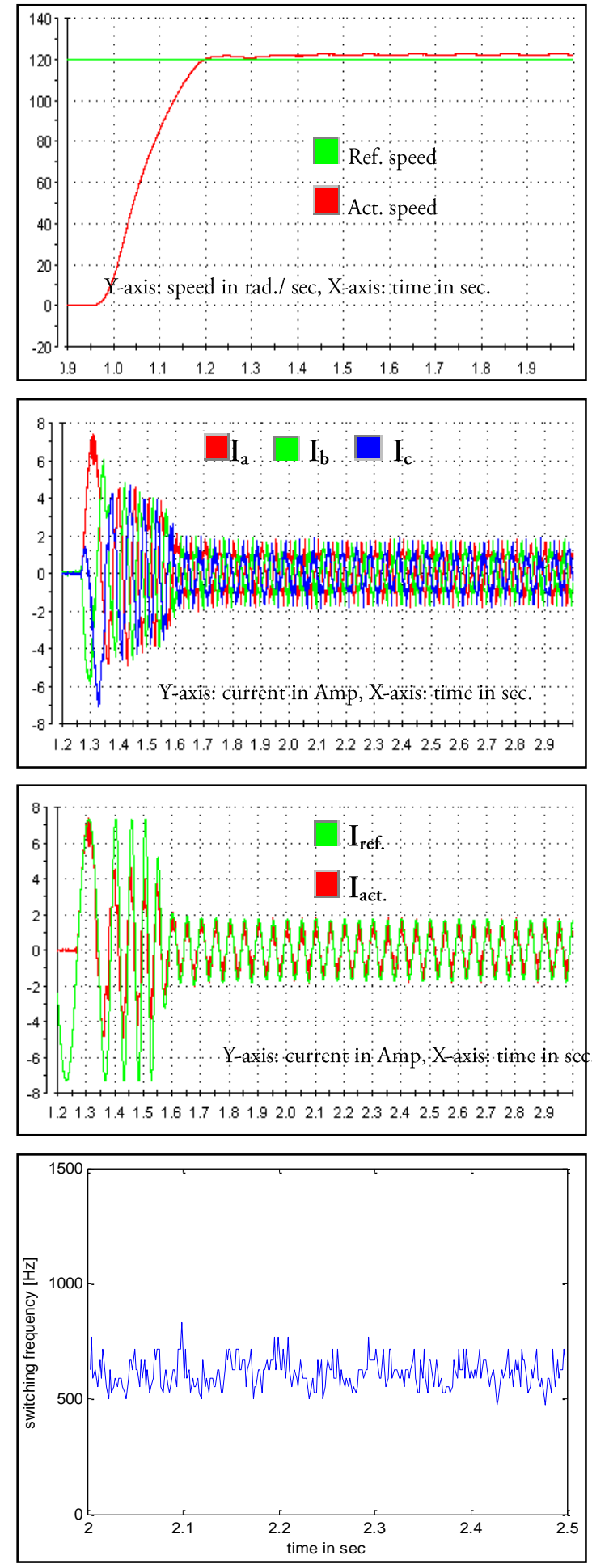

Fig. 9. Experimental results of the proposed HCC

\section{CONCLUSION}

A new concept of online variation of hysteresis band is proposed to control the switching frequency variation in hysteresis 
controller-based two-level PWM inverter fed IM drives. The suggested digital adaptive hysteresis current control is shown to be particularly simple and effective in achieving constant switching frequency, minimum torque and flux ripples. The proposed technique is characterized by a better stability; it allows also an improvement of the load current waveform in term of THD. The performances of the proposed digital hysteresis current control are verified by simulations and experiment.

\section{APPENDIX}

Induction motor parameters: $1.5 \mathrm{~kW}$, three phase, rated voltage: $380 \mathrm{~V}$ line to line, $50 \mathrm{~Hz}$, rated speed: $1400 \mathrm{rpm}$, four poles, $\mathrm{R}_{\mathrm{s}}=$ $7.4826 \Omega, \mathrm{R}_{\mathrm{r}}=3.684 \Omega, \mathrm{L}_{\mathrm{s}}=\mathrm{L}_{\mathrm{r}}=0.4335 \mathrm{H}$, and $\mathrm{L}_{\mathrm{m}}=0.4114 \mathrm{H}$

\section{REFERENCES}

[1] J. Holtz, "Pulsewidth modulation of electronic power converters," Invited Paper, Proceedings of the IEEE, Vol. 82(8), August 1994, pp. 11941214.

[2] M. A. Rahman, T. S. Radwan, A. M. Osheiba, and A. E. Lashine, "Analysis of current controllers for voltage-source inverter," IEEE Trans. Ind. Electron., Vol. 44(4), August 1997, pp. 477-485.

[3] M. P. Kazmierkowski, and L. Malesani, "Current control techniques for three-phase voltage-source PWM converters: a survey," IEEE Trans. Ind. Electron., Vol. 45(5), October 1998, pp. 691703.

[4] D.M. Brod, and D.W., Novotny, "Current control of VSI-PWM inverters, ” IEEE Trans. Ind. Appl., Vol.IA-21(4) , 1985, pp. 562-570

[5] A. Nabae, S. Ogasawara, and H. Akagi, "A novel control scheme for current-controlled PWM inverters,” IEEE Trans. Ind. Appl., Vol. IA-22(4), Jul./Aug. 1986, pp. 697-701.

[6] M. P. Kazmierkowski, M. A. Dzieniakowski, and W. Sulkowski, "Novel space vector based current controllers for PWM-inverters," IEEE Trans. Power Electron., Vol. 6(1), Jan, 1991, pp. 158166.
[7] I. Nagy, "Novel adaptive tolerance band based PWM for field-oriented control of induction machines," IEEE Trans. Ind. Electron., Vol. 41, Aug. 1994, pp. 406-417.

[8] I.Nagy, Z. Suto, and L., Backhausz, "Periodic states of hysteresis current control of induction motor,". Proc. 29 $9^{\text {th }}$ European Conf. on Intelligent Motion (PCIM), Nurnberg, Germany, May 1996, pp. 605-619

[9] M. P. Kazmierkowski and W. Sulkowski, "A novel vector control scheme for transistor PWM inverter-fed induction motor drive," IEEE Trans. Ind. Electron., Vol. 38(1), Feb. 1991, pp. 41-47.

[10] I. Nagy and L. Backhausz, "Current control of VSI-PWM inverters for vector controlled drives," in Proc. 25th Eur. Conf. PCIM, Nurnberg, Germany, Jun. 28-30, 1994, pp. 397-413.

[11] V. M. Mistry, S. P. Waikar, K. Gopakumar, L. Umanand, and V. T. Ranganathan, "A multi axis space phasor based current hysteresis controller for PWM inverters," EPE J., Vol. 10(1), Apr. 2000, pp. 17-25.

[12] M. R. Baiju, K. K. Mohapatra, R. S. Kanchan, P. N. Tekwani, and K. Gopakumar, "A space phasor based current hysteresis controller using adjacent inverter voltage vectors with smooth transition to six step operation for a three phase voltage source inverter,” EPE J., Vol.15(1), Feb. 2005, pp. 3647.

[13] K. A. Corzine, "A hysteresis current-regulated control for multi-level drives," IEEE Trans. Energy Convers., Vol.15(2), Jun. 2000, pp. 169175.

[14] P. N. Tekwani, R. S. Kanchan, and K. Gopakumar, "Current-error pacevector-based hysteresis PWM controller for three-level voltage source inverter fed drives," Proc. Inst. Electr. Eng.-Electric Power Applica ions, Vol.152(5), Sep. 2005, pp. 1283-1295.

[15] V. Chereau, F. Auger, and L. Loron, "A new three-phase varying-band hysteresis current controller for voltage -source inverters," PEDS., 27-30 Nov. 2007, pp. 1179-1186.

[16] A. Tripathi, and P. C. Sen, "Comparative analysis of fixed and sinusoidal band hysteresis current controllers for voltage source inverters," IEEE Trans. Ind. Electron., Vol.39(1), February 1992, pp. 63-73.

[17] K. M. Rahman, M. Rezwan, M. A. Choudhury, and M. A. Rahman, "Variable-band hysteresis 
current controllers for PWM voltage-source inverters," IEEE Trans. Power Electron., Vol. 12(6), November 1997, pp. 964-970.

[18] Q. Yao, and D. G. Holmes, "A simple, novel method for variablehysteresis-band current control of a three phase inverter with constant switching frequency," Conference Record. IEEE IAS Annual Meet., Vol.2, 2-8 October 1993, pp. 1122-1129.

[19] T. W. Chun, and M. K. Choi, "Development of adaptive hysteresis band current control strategy of PWM inverter with constant switching frequency," Conference Proc. IEEE APEC, Vol.1, 3-7 March 1996, pp. 194-199.

[20] L. Malesani, P. Mattavelli, and P. Tomasin, "Improved constant frequency hysteresis current control for VSI inverters with simple feedforward bandwidth prediction," IEEE Trans. Ind. Applicat., Vol.33(5), Sept./Oct. 1997, pp. 11941202.

[21] F.M. Abdel-Kader, E.E. Elkholy, A.E. Kalas, and M. Dessouki, "New Variable Band Hysteresis PWM Current Controlled VSI Fed Induction Motor for Controlling Switching Frequency Variation," $13^{\text {th }}$ Middle East Power System Conference, MEPCON'2009, Assuit, Egypt, Dec.20-23, 2009, pp.620-625. 


\section{حاكم التيار ذو النطاق التخلفي لمقطع جه يغذي محرك حثي}

$$
\begin{aligned}
& \text { علوي الخولي1، أحمد كلس2 ، محمد الثحات دسوفي1 } \\
& 1 \text { قسم الهندسة الكهربائية - كلية الهندسة بر ابغ - جامعة الملك عبد العزيز - المملكة العربية السعودية } \\
& 2 \text { قسم الهندة الكهربائية - كلية الهندة بلورسة بعيد - جامعة بور سعيد }
\end{aligned}
$$

الملخص:

من أكثر الششاكل الخاصة بمتحكم التيار التخلفى التقليدى ذو المستويين هو تغير تردد الفصل والتوصيل على نطاق سر عات تثغيل واسعة (كبيرة) لعاكس الجهد المغذى للمحركات التأثيرية. فى هذا البحث نم تقديم طريقة جديدة لاختيار شريط متغير لهذا الحاكم للتحكم فى تردد الفصل و التوصيل لعاكس الجهد ذو المستويين المغذى للمحركات التأثبرية على نطاق سرعات واسعة. يعتمد هذا المبدأ الجديد على تغير شريط هذا الحاكم لحظيا معتمدا فى ذلك على القيمة اللحظية للتيار وكذلك التغير فى التبار وذلك خلال كل فترة أخذ العينات لتحديد قيمة الثريط الجديدة للفترة التالية. تم عمل محاكاه للنموذج المقترح و تقديم النتائج النظرية و العملية للتحقق من جدوى النموذج المقترح و التى أثنتت انه بتطبيق النموذج المقترح تم الحصول على تردد فصل وتوصيل ثابت إضافة إلى تحسين خصائص الاداء للمحرك التأثيرى. 